\title{
Development of High-Yielding Rice Varieties Suitable for Swampy Lands in Indonesia
}

\author{
Indrastuti A. Rumanti ${ }^{1}$, Yudhistira Nugraha ${ }^{1}$, Rina H. Wening ${ }^{1}$, Zennia Jean C. Gonzaga ${ }^{2}$, Suwamo ${ }^{1}$, \\ Anggiani Nasution, ${ }^{1}$ Dede Kusdiaman ${ }^{1}$, Endang M. Septiningsih ${ }^{2} * \dagger$ \\ ${ }^{1}$ Indonesian Agency for Agricultural Research and Development, J1. Pasar Minggu, Jakarta 12540, Indonesia \\ ${ }^{2}$ International Rice Research Institute, DAPO Box 7777, Metro Manila, Philippines
}

\begin{abstract}
Productivity of swampy land rice varieties in Indonesia remains low due to abiotic and biotic stresses. Iron toxicity, submergence and long-term flooding are common problems that affect plant growth, sometimes leading to total crop loss. Meanwhile, rice blast, rice tungro virus (RTV), and bacterial leaf blight (BLB) can also lead to severe yield loss. These stresses could be overcome by an integrative approach of cultural practices and planting multi-stress tolerant rice. Here we describe the development of new high-yielding varieties that are adapted to the swampy land environments in Indonesia with multi-stress tolerance to diverse abiotic and biotic stresses. Multi-environmental trials were performed in nine locations to screen for several abiotic and biotic stresses in the field and greenhouse in 2012 and 2013. This study identified promising rice lines that had high grain yield as well as tolerance to iron toxicity and submergence, resistance to BLB and RTV, and good grain quality. The best line was B11377F-MR-34-2, derived from a double cross among Cinglonik, IRBB7, Mamberamo and IR64. It was confirmed that this advanced breeding line carries the submergence tolerance gene, SUB1, through expression analysis of the SUB1A gene. Another promising line was B11586F-MR-11-2-2, having iron toxicity tolerance, resistance to RTV, and high milling recovery. Moreover, these lines have passed the Indonesian national variety release committee and have been named as Inpara8 and Inpara9, and are targeted for dissemination and adoption in the swampy areas.
\end{abstract}

Keywords Bacterial leaf blight, Iron toxicity, Rice Tungro virus, Submergence, Swampy land, Multi-environmental trials

\section{INTRODUCTION}

Swampy land is one of the potential areas for future development and expansion of rice cultivation. Swampy areas in Indonesia are spread across four major islands, Sumatra, Kalimantan, Sulawesi, and Papua, reaching 33.4 million ha, including 20.1 million ha of tidal swamp and 13.3 million ha of freshwater swamp (Alihamsyah 2004). However, less than 1 million ha has been used for rice cultivation. Moreover, the productivity of rice in these areas was low, with only 2-4 t/ha (Hairmansis et al. 2013; Nugraha et al. 2016), compared to the national productivity of $5.1 \mathrm{t} / \mathrm{ha}$ (http://www.bps.go.id/tnmn_ pgn.php).
Increasing the productivity of swampy rice is one of the key targets to meet the growing national demand for rice in Indonesia. However, an integrated effort needs to be deployed to apply the right technologies to overcome enormous challenges in the swampy areas, including abiotic and biotic stresses.

Varying soil conditions and dynamic changes in water depth due to the changes of tidal sea level impose multiple abiotic stresses on rice crops. These problems are largely associated with water availability and quality, such as flash floods, stagnant water, drought, and salinity, as well as the nutrient status of soils, including nutrient deficiencies and toxicities, and low pH (Alihamsyah et al. 2003). On the

Received October 18, 2016; Revised November 12, 2016; Accepted November 12, 2016; Published November 30, 2016

*Corresponding author Indrastuti A. Rumanti, indrastuti.apri@gmail.com, Tel: +62-21-780-6202, 780-5395, Fax:+62-21-780-0644

Endang M. Septiningsih, eseptiningsih@tamu.edu, Tel: +1-979-845-7527, Fax: +1-979-845-0456

${ }^{\dagger}$ Present address: Department of Soil and Crop Sciences, Texas A\&M University, College Station, TX 77843, USA. 
other hand, biotic stresses such as rice pests and diseases can also significantly challenge the production of rice in these areas. The important pests in swampy areas are rats, stem borer, Leptispa beetle, rice hispa, armyworms, grasshopper, mole cricket, black bug, brown planthopper (BPH), green leafhopper (GLH), and stink bug. While the common diseases include leaf and neck blast, rice tungro virus (RTV), bacterial leaf blight (BLB), brown spots, and leaf scald (Rhynchosporium oryzae) (Asikin 2015). These various stresses fluctuate seasonally and can adversely affect rice growth and productivity.

Physiological and agronomic traits related to tolerance to various abiotic stresses that may affect rice crops in swampy areas have been previously investigated (Sahrawat 2005; Castillo et al. 2007; Singh et al. 2009; Henry et al. 2012; Kato et al. 2014). Likewise, quantitative traits loci and genes for tolerance to various abiotic stresses, including drought, salinity, submergence during vegetative stage, submergence during germination, stagnant flooding and iron toxicity have been identified and used in molecular breeding programs (Ismail et al. 2007; Thomson et al. 2010; Iftekharuddaula et al. 2011; Septiningsih et al. 2012; Septiningsih et al. 2013b; Baltazar et al. 2014; Dixit et al. 2014; Kretzschmar et al. 2015; Toledo et al. 2015; Gonzaga et al. 2016; Iftekharuddaula et al. 2016a; Singh et al. 2016). In addition, elite breeding lines tolerant to multiple abiotic stresses have been developed through conventional breeding (Gregorio et al. 2002; Kumar et al. 2008; Collard et al. 2013a; Collard et al. 2013b). Allele mining to tap new genes and novel beneficial alleles from diverse germplasm for abiotic stresses have also been explored (Fukao et al. 2009; Li et al. 2011; Niroula et al. 2012; Iftekharuddaula et al. 2016b; Shah et al. 2016). The improved breeding lines developed from both conventional and molecular breeding and the available DNA markers can be used to develop new tolerant lines with multi-abiotic stress tolerance in more challenging areas, such as in the swampy lands.

Developing improved breeding material tolerant to most of these abiotic and biotic stresses coupled with good management practices can significantly reduce the crop damage and yield reduction. Utilization of high-yielding rice varieties tolerant to the prevalent stresses involves no additional costs to farmers and can enhance and stabilize productivity in both rainfed and irrigated ecosystems (Ismail and Tuong 2009; Thomson et al. 2009; Septiningsih et al. 2013a). The key traits needed for successfully growing rice in the swampy areas include improvement of yield potential, tolerance to abiotic stresses such as submergence, stagnant flooding, salinity, and $\mathrm{Fe}$ and $\mathrm{Al}$ toxicity, resistance to major pests and diseases including $\mathrm{BPH}$, blast, BLB, and tungro, as well as improving the grain quality. Here we reported the development of high-yielding improved lines having tolerance to multiple abiotic and biotic stresses and good grain quality, which show promise to increase rice production in the swampy lands in Indonesia.

\section{MATERIALS AND METHODS}

\section{Plant material}

Nine promising swampy rice breeding lines, namely: IR84941-12-1-2, IR83835-95-1-1-3, B11377F-MR-34-2, B11586F-MR-11-2-2, B10891B-MR-3-KN-4-1-1-MR-1, BMIP-46-4-1, AGH42-2-3, AGH43-1-2, GH137-7-SKI$B$, were used in this study along with three check varieties, IR42, Inpara2, and Martapura. Several other varieties were also used as specific checks, depending on the type of abiotic or biotic screening test being performed. IR8494112-1-2 and IR83835-95-1-1-3 were originally from the International Rice Research Institute (IRRI), Los Baños, Philippines, but have undergone selection at the Indonesian Center for Rice Research (ICRR), Sukamandi. B11377FMR-34-2, B11586F-MR-11-2-2, and B10891B-MR-3KN-4-1-1-MR-1 were internally bred in ICRR. BMIP-464-1 was from the Indonesian Center for Agricultural Biotechnology and Genetic Resources Research and Development (ICABIOGRAD), Bogor. The last three breeding lines were obtained from Bogor Agriculture University (BAU).

\section{Submergence screening}

Testing of swampy rice material to submergence tolerance during vegetative stage was conducted on an artificial bed at ICRR, Sukamandi, as described by 
Septiningsih et al. (2015). An additional screening for a subset of the germplasm was also performed at the screen house at IRRI, Los Baños, Philippines. Data from IRRI was analyzed using PBTools. IR42 and FR13A were used as the susceptible and the tolerant checks, respectively. Plants were completely submerged under $1 \mathrm{~m}$ water at 14 days after transplanting. Water was drained at 14 days after submergence, when IR42 plants were mostly dead. The survival rate was counted seven days after desubmergence.

\section{SUB1A allele identification and expression analysis}

The SUB1-specific markers GnS2, RM8300 and ART5 were used to further investigate the submergence tolerant line identified based on phenotyping (Neeraja et al. 2007; Septiningsih et al. 2009; Septiningsih et al. 2013a). DNA from one week-old seedlings was extracted following a standard protocol (Zheng et al. 1995). Total RNA was isolated using TRIzol (Gibco) from 14d-old submerged seedlings as described in Xu et al. (2006). The SUB1A203 primer was used for the reverse transcription polymerase chain reaction (RT-PCR) (Septiningsih et al. 2009). PCR and RT-PCR analysis were performed as described by $\mathrm{Xu}$ et al. (2006).

\section{Screening of Fe toxicity}

Screening for Fe toxicity was conducted in the acid sulfate field in Karang Agung, South Sumatra. The experimental design was check stripe, with a tolerant check Mahsuri and a sensitive check IR64. Screening of iron toxicity was conducted in the field under an average total iron $\left(\mathrm{Fe}^{2+}\right)$ concentration of $592 \mathrm{ppm}$. Twenty-one-day-old rice seedlings were transplanted with one seedling per hill. Each entry was planted in a plot of $50 \times 500 \mathrm{~cm}$, with a spacing of $25 \times 25 \mathrm{~cm}$. Scoring of Fe toxicity symptoms was performed at the vegetative stage based on the Standard Evaluation System (SES) for Rice from IRRI and INGER (2014) (Supplementary Table 1).

\section{Screening of blast disease}

Screening for blast disease was performed at the seedling stage. Pyricularia grisea isolates were propagated on potato dextrose agar for 5-7 days, then transferred to sporulation media of oatmeal agar for 12 days, with density of spores of $2 \times 10^{5} / \mathrm{ml}$. Inoculation was performed at 18-21 days after sowing. Inoculated plants were incubated in a humid room for 48 hours, and then were moved to a screen house with humidity over $90 \%$ at ICRR, Sukamandi. Scoring was performed at seven days after inoculation based on the SES scale from IRRI and INGER (2014) (Supplementary Table 2).

\section{Screening of bacterial leaf blight}

Artificial inoculation of BLB pathotype IV and VIII was performed following the clipping method at 55-60 days after sowing. Inoculum was developed from Xanthomonas oryzae culture grown on Wakimoto media. Scoring of the symptoms was performed at two and three weeks after inoculation based on the SES from IRRI and INGER (2014) (Supplementary Table 3).

\section{Screening of tungro virus}

Screening for tolerance to tungro virus was performed artificially. Tungro virus was transmitted by GLH (Nephotettix virescens) at ten days after planting. Screening was carried out in two phases. The first phase was a mass screening and the second phase was a test tube experiment to avoid escape. This was done by forcing the insect to bite the infected leaf and facilitating virus transfer from leaf to insect (due to no feeding choice) for a period of 24 hours. The inoculums were from Garut and Subang, West Java. Scoring of the symptom was performed at seedling stage, based on the SES scale from IRRI and INGER (2014) (Supplementary Table 4).

A disease index (DI) for the genotypes can be calculated as follows:

$$
\mathrm{DI}=\frac{\mathrm{n}(1)+\mathrm{n}(3)+\mathrm{n}(5)+\mathrm{n}(7)+\mathrm{n}(9)}{\mathrm{tn}}
$$

Note: $\mathrm{n}=$ number of plants showing a reaction in the scale $1,3,5,7$, or 9

tn=total number of plant scored

On the basis of the DI, the genotypes can be classified as resistant/tolerant: 0-3, moderate: 4-6, or susceptible: 7-9.

\section{Multi-environmental trials}

Multi-environment trials were performed in the 
following locations and seasons: (1) Subdistrict Kayu Agung, District Ogan Komering Ilir, South Sumatra, in dry season (DS) 2012 (fresh water swamp); (2) Subdistrict Karang Agung, District Banyuasin, South Sumatra, in wet season (WS) 2013 (tidal swamp); (3) Subdistrict Karang Agung, District Banyuasin, South Sumatra, in DS 2013 (tidal swamp); (4) Subdistrict Karang Agung, District Banyuasin, South Sumatra, in DS 2013 (tidal swamp with acid sulphate soil toxicity); (5) Subdistrict Karang Agung, District Banyuasin, South Sumatra, in WS 2013 (tidal swamp with acid sulphate soil toxicity); (6) Subdistrict Barabai, District Barito Koala, South Kalimantan, in DS 2013 (tidal swamp); (7) Subdistrict Banjar, South Kalimantan, in DS 2013 (tidal swamp); (8) Subdistrict Ketapang, West Kalimantan, in DS 2013 (tidal swamp); and (9) Subdistrict Kayu Agung, District Ogan Komering Ilir, South Sumatra, in DS 2012 (fresh water swamp). Twelve entries were used, including the nine promising lines and the three popular varieties as checks (IR42, Inpara2, and Martapura). Each rice entry was planted in a plot of $4 \times 5 \mathrm{~m}$, following randomized complete block design (RCBD) with three replications. Twenty-oneday-old seedlings were transplanted with $25 \times 25 \mathrm{~cm}$ spacing and 1-2 seedlings per hill. All the recommended rice cultural practices for growing rice were applied. Grain yield per plot (kg/plot) was measured and used to estimate yield per hectare. The pooled analysis of variance was used to analyze genotype $\times$ environment $(\mathrm{G} \times \mathrm{E})$ interaction and the stability of the genotypes across environments. The stability of yield performance for each rice genotype was calculated using regression (Finlay and Wilkinson 1963) and additive main effects and multiplicative interaction (AMMI) model analysis (Gauch et al. 2008). A stability model was analyzed using methods of Eberhart and Russell (1966).

\section{RESULTS}

\section{Response to abiotic stresses}

Eight promising lines, except for IR83835-95-1-1-3, were highly tolerant to Fe toxicity; while eight lines were susceptible to complete submergence during vegetative stage, with the exception of one line, B11377F-MR-34-2 (Table 1). The survival rate of this line was comparable to those of FR13A and IR64-Sub1. The tolerance allele of B11377F-MR-34-2 to submergence was assayed using three SUB1 markers, GnS2, ART5 and SC3 (Fig. 1). Interestingly, the alleles of B11377F-MR-34-2 in all three markers were the same as the allele of the susceptible check, IR42. However, upon expression analysis study of the SUB1A gene, the gene expression of SUB1A in

Table 1. Response of promising rice lines to submergence and $\mathrm{Fe}$ toxicity stresses.

\begin{tabular}{clcc}
\hline \hline No. & \multicolumn{1}{c}{ Promising lines/check varieties } & Submergence $(14 \text { days })^{\mathrm{z})}$ & Fe toxicity ${ }^{\mathrm{z})}$ \\
\hline 1 & IR84941-12-1-2 & $\mathrm{S}$ & $\mathrm{T}$ \\
2 & IR83835-95-1-1-3 & $\mathrm{S}$ & $\mathrm{MS}$ \\
3 & BMIP-46-4-1 & $\mathrm{S}$ & $\mathrm{T}$ \\
4 & AGH42-2-3 & $\mathrm{S}$ & $\mathrm{T}$ \\
5 & AGH43-1-2 & $\mathrm{S}$ & $\mathrm{T}$ \\
6 & GH137-7-SKI-B & $\mathrm{T}$ & $\mathrm{T}$ \\
7 & B11377F-MR-34-2 & $\mathrm{S}$ & $\mathrm{T}$ \\
8 & B11586F-MR-11-2-2 & $\mathrm{S}$ & $\mathrm{T}$ \\
9 & B10891B-MR-3-KN-4-1-1-MR-1 & $\mathrm{S}$ & $\mathrm{T}$ \\
10 & IR42 (Check for S to submergence) & $\mathrm{S}$ & $\mathrm{MS}$ \\
11 & Inpara2 & $\mathrm{S}$ & $\mathrm{MT}$ \\
12 & Martapura & - & $\mathrm{T}$ \\
& Mahsuri (check for T to Fe toxicity) & - & $\mathrm{T}$ \\
& IR64 (check for S to Fe toxicity) & $\mathrm{T}$ & $\mathrm{S}$ \\
& FR13A (check for T to submergence) & \multicolumn{2}{c}{-} \\
\hline
\end{tabular}

${ }^{\mathrm{z})} \mathrm{S}$ : susceptible, T: tolerant, MS: moderately susceptible, MT: moderately tolerant. 

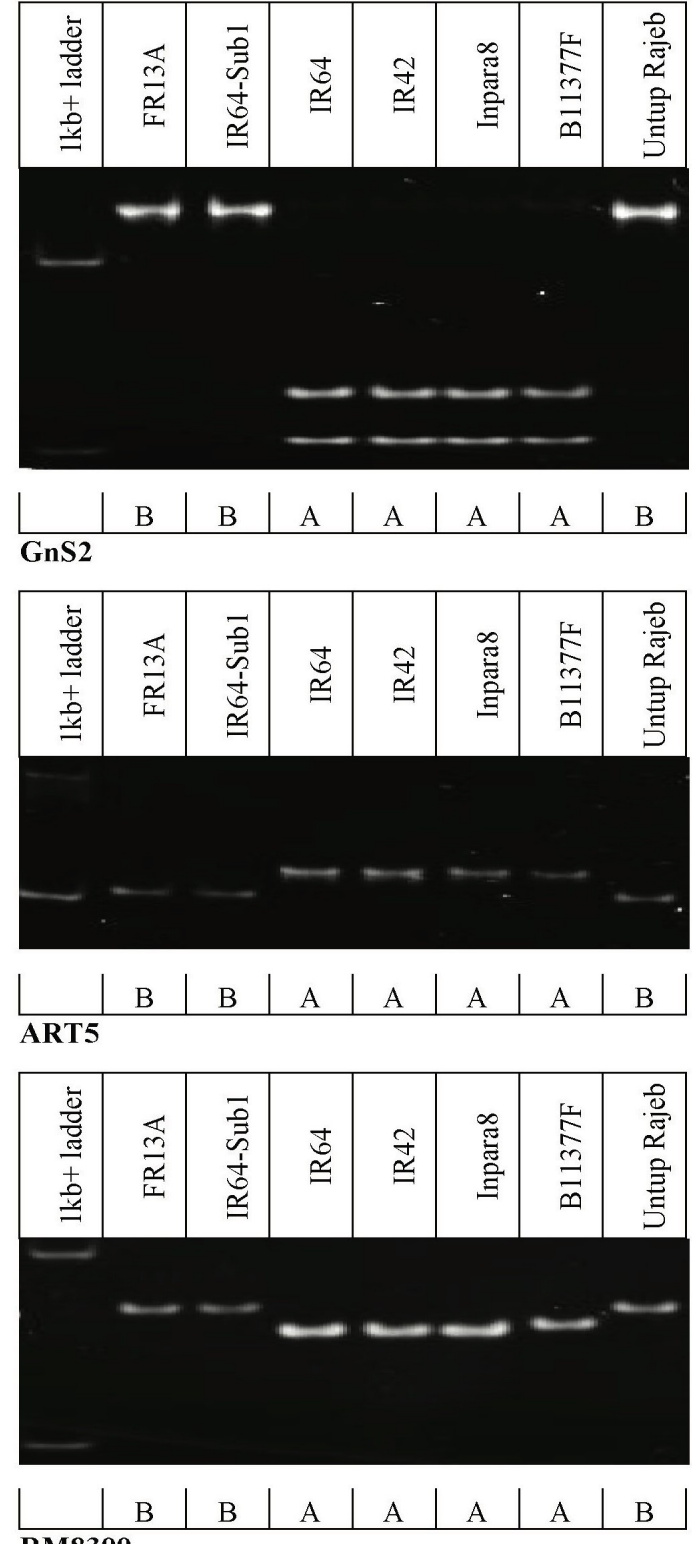

RM8300

Fig. 1. Different alleles of GnS2, ART5 and RM8300 in the $S U B 1$ gene region.
B11377F-MR-34-2 was as strong as those of in the submergence tolerant parents, FR13A and IR64-Sub1 (Fig. 2). A susceptible Indonesian variety, Padi Cina, was used in this analysis and both allele assessment with the three DNA markers and $S U B 1 A$ gene expression confirmed its susceptibility. An Indonesian tolerant landrace, Untup Rajeb was also investigated and based on allele assessment and $S U B 1 A$ gene expression analysis, the submergence tolerance of this variety comes from the $S U B 1 A$ gene. Independent screening of submergence tolerance in a controlled submergence tank in IRRI confirmed the tolerance of B11377F-MR-34-2 and Untup Rajeb (Supplementary Table 5).

\section{Response to biotic stresses}

\section{Blast}

Entries showed different responses to inoculation of four predominant blast races in Indonesia (Table 2). B11377FMR-34-2 was moderately resistant to blast race 133, and moderately susceptible to races 073 and 173 . This was similar to the IR42 response and a better response than in Inpara2. Martapura was moderately resistant to race 033 and 133, but susceptible to the other two races. The most resistant line, BMIP-46-4-1, was resistant to race 033, moderately resistant to race 133 and 173 , and moderately susceptible to race 073 . The most susceptible lines were IR84941-12-1-2 and IR83835-95-1-1-3.

\section{Bacterial leaf blight}

The elite lines had different reactions to the three pathotypes of BLB during the vegetative stage (Table 3 ). Six of the elite lines had better resistance to BLB compared to the three checks (IR42, Inpara2 and Martapura).
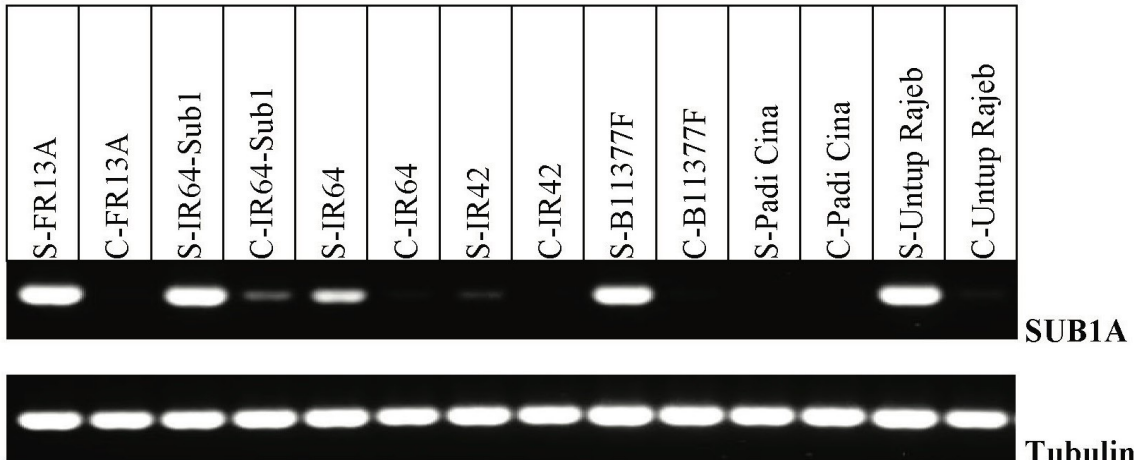

Tubulin
Fig. 2. Reverse transcription polymerase chain reaction of SUB1A (top) with Tubulin as control (bottom) shown below each sample. Total RNA were isolated from leaves of 14-d-old seedlings submerged for 6 hours (S) and non-submerged controls (C). 
Table 2. Reaction of elite swampy rice genotypes to four blast disease isolates.

\begin{tabular}{clcccc}
\hline \multirow{2}{*}{ No. } & & \multicolumn{4}{c}{ Reaction to blast diseases ${ }^{\text {z) }}$} \\
\cline { 3 - 6 } & & Race 033 & Race 073 & Race 133 & Race 173 \\
\hline 1 & IR84941-12-1-2 & $\mathrm{S}$ & $\mathrm{S}$ & $\mathrm{S}$ & $\mathrm{S}$ \\
2 & IR83835-95-1-1-3 & $\mathrm{S}$ & $\mathrm{S}$ & $\mathrm{S}$ & $\mathrm{S}$ \\
3 & BMIP-46-4-1 & $\mathrm{R}$ & $\mathrm{MS}$ & $\mathrm{MR}$ & MR \\
4 & AGH42-2-3 & $\mathrm{S}$ & $\mathrm{S}$ & $\mathrm{MS}$ & $\mathrm{MS}$ \\
5 & AGH43-1-2 & $\mathrm{S}$ & $\mathrm{S}$ & $\mathrm{MS}$ & $\mathrm{S}$ \\
6 & GH137-7-SKI-B & $\mathrm{S}$ & $\mathrm{MS}$ & $\mathrm{S}$ & $\mathrm{MS}$ \\
7 & B11377F-MR-34-2 & $\mathrm{S}$ & $\mathrm{MS}$ & $\mathrm{MR}$ & $\mathrm{MS}$ \\
8 & B11586F-MR-11-2-2 & $\mathrm{S}$ & $\mathrm{S}$ & $\mathrm{MS}$ & $\mathrm{S}$ \\
9 & B10891B-MR-3-KN-4-1-1-MR-1 & $\mathrm{MR}$ & $\mathrm{S}$ & $\mathrm{S}$ & $\mathrm{S}$ \\
10 & IR42 & $\mathrm{MS}$ & $\mathrm{MS}$ & $\mathrm{MR}$ & $\mathrm{MS}$ \\
11 & Inpara2 & $\mathrm{MS}$ & $\mathrm{MS}$ & $\mathrm{MS}$ & $\mathrm{MS}$ \\
12 & Martapura & $\mathrm{MR}$ & $\mathrm{S}$ & $\mathrm{MR}$ & $\mathrm{S}$ \\
& Kencana Bali (S check) & $\mathrm{S}$ & $\mathrm{S}$ & $\mathrm{S}$ & $\mathrm{S}$ \\
& Asahan (R check) & $\mathrm{R}$ & $\mathrm{R}$ & $\mathrm{R}$ & $\mathrm{R}$ \\
\hline
\end{tabular}

${ }^{{ }^{z}} \mathrm{~S}$ : susceptible, R: resistant, MR: moderately resistant, MS: moderately susceptible.

Table 3. Reaction of elite swampy rice genotypes to three BLB pathotypes.

\begin{tabular}{clccc}
\hline \multirow{2}{*}{ No. } & & \multicolumn{3}{c}{ Reaction to BLB B $^{z)}$} \\
\cline { 3 - 5 } & & Pathotype III & Pathotype IV & Pathotype VIII \\
\hline 1 & IR84941-12-1-2 & MR & MS & MS \\
2 & IR83835-95-1-1-3 & $\mathrm{R}$ & MS & MS \\
3 & BMIP-46-4-1 & $\mathrm{R}$ & MS & MS \\
4 & AGH42-2-3 & MR & MS & MS \\
5 & AGH43-1-2 & $\mathrm{R}$ & MS & MS \\
6 & GH137-7-SKI-B & $\mathrm{R}$ & MS & MS \\
7 & B11377F-MR-34-2 & $\mathrm{R}$ & MR & MR \\
8 & B11586F-MR-11-2-2 & $\mathrm{R}$ & $\mathrm{S}$ & MS \\
9 & B10891B-MR-3-KN-4-1-1-MR-1 & MR & MS & MS \\
10 & IR42 & MR & MS & MS \\
11 & Inpara2 & MR & MS & MS \\
12 & Martapura & MR & MS & MS \\
& IR64 (S check) & MS & S & S \\
& IRBB5 (R check) & MR & MR & MR \\
& IRBB7 (R check) & R & R & R \\
\hline
\end{tabular}

${ }^{2)}$ BLB: bacterial leaf blight, MR: moderately resistant, R: resistant, MS: moderately susceptible, S: susceptible.

B11377F-MR-34-2 showed better resistance to BLB disease than IRBB5; it was resistant to pathotype III and moderately resistant to pathotype IV and VIII. This line always showed resistance to BLB across locations during multi-location yield trials (data not shown). The rest of the elite lines were moderately resistant or resistant to BLB pathotype III; but moderately susceptible to pathotype VIII and moderately susceptible or susceptible to pathotype IV.
IR42, Inpara2 and Martapura had similar reactions in which all of them were moderately resistant to pathotype III, and moderately susceptible to pathotypes IV and VIII.

\section{Tungro virus}

In the screening to tungro virus, seven elite lines, including B11377F-MR-34-2 were susceptible to two most virulent tungro virus strains in Indonesia, the Purwakarta and Garut inoculums (Table 4). Similar reactions were 
Table 4. Reaction of elite swampy rice genotypes to RTV.

\begin{tabular}{clcc}
\hline \hline \multicolumn{1}{c}{ Lines/varieties } & \multicolumn{2}{c}{ Reaction to RTV } \\
\hline 1 & & Inoculum Garut & Inoculum Purwakarta \\
\cline { 3 - 3 } 2 & IR84941-12-1-2 & $\mathrm{S}$ & $\mathrm{S}$ \\
3 & IR83835-95-1-1-3 & $\mathrm{S}$ & $\mathrm{S}$ \\
4 & BMIP-46-4-1 & $\mathrm{S}$ & $\mathrm{S}$ \\
5 & AGH42-2-3 & $\mathrm{S}$ & $\mathrm{S}$ \\
6 & AGH43-1-2 & $\mathrm{S}$ & $\mathrm{S}$ \\
7 & GH137-7-SKI-B & $\mathrm{S}$ \\
8 & B11377F-MR-34-2 & $\mathrm{S}$ \\
9 & B11586F-MR-11-2-2 & $\mathrm{S}$ & $\mathrm{R}$ \\
10 & B10891B-MR-3-KN-4-1-1-MR-1 & $\mathrm{S}$ & $\mathrm{MR}$ \\
11 & IR42 & $\mathrm{R}$ & $\mathrm{S}$ \\
12 & Inpara2 & $\mathrm{MR}$ & $\mathrm{S}$ \\
& Martapura & $\mathrm{S}$ & $\mathrm{S}$ \\
\end{tabular}

${ }^{\text {z) }} \mathrm{RTV}$ : rice tungro virus, $\mathrm{S}$ : Susceptible, R: Resistant, MR: moderately resistant.

observed in all local checks, IR42, Inpara2 and Martapura. However, line B11586F-MR-11-2-2 showed highly resistance to both inoculums, which was comparable to the resistant check, Tukad Petanu. Another elite line, B10891B-MR-3-KN-4-1-1-MR-1, was moderately tolerant to both inoculums.

\section{Adaptability of swampy rice lines}

Based on stability parameters, GH137-7-SKI-B had stable yield because the regression coefficient (bi) was close to unity (1.04) and the deviation from regression (S2di) was 0.22; however, it did not have the highest yield. B11586F-MR-11-2-2 was categorized as having stable yield as well because it had high average yield (4.16 t/ha), regression coefficient close to unity (1.02), and the relatively small deviation of 0.58 from regression. On the other hand, B11377F-MR-34-2 had a bi value of 0.67 but had the highest average yield. It was confirmed by AMMI2 biplot that B11586F-MR-11-2-2 (line no. 8) was closer to the origin and hence this line was adaptable to different environmental conditions; while B11377F-MR-34-2 (line no. 7) was further away from the origin which indicated that its performance was more affected by different environmental conditions. IR83835-95-1-1-3 also had high and stable yield; however, this variety was very susceptible to RTV, all races of blast and iron toxicity (Fig. 3). The

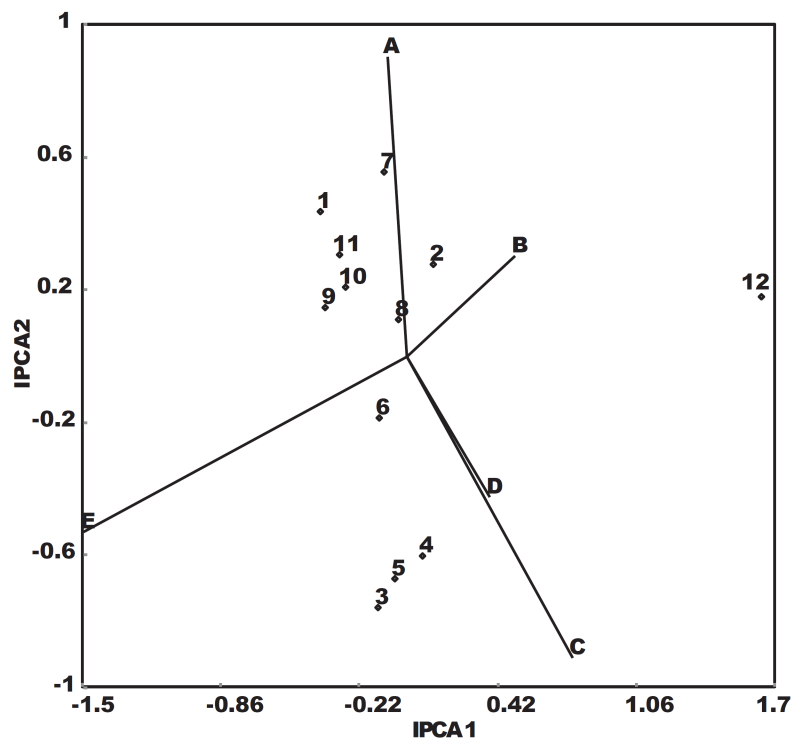

Fig. 3. Additive main effects and multiplicative interaction 2 Biplot for grain yield showing the interaction of Interaction Principal Component Axes (IPCA)2 against IPCA1 scores of 12 rice genotypes (1-12) in 9 environments (A-E; in this case some of the environments were similar since they were in the same districts).

trials were conducted under optimum conditions, where most stresses could be controlled; therefore, IR83835-951-1-3 had a good yield, ranged from 3.80 to $5.39 \mathrm{t} / \mathrm{ha}$ (Table 5). 
Table 5. Stability parameter of nine promising lines along with check varieties across nine locations in Sumatra and Kalimantan.

\begin{tabular}{clcccc}
\hline \hline No. & \multicolumn{1}{c}{ Genotypes/check varieties } & Average yield (t/ha) & Yield range $(\mathrm{t} / \mathrm{ha})$ & $\mathrm{Bi}^{\mathrm{z})}$ & $\mathrm{S}^{2} \mathrm{di}^{\mathrm{y})}$ \\
\hline 1 & IR84941-12-1-2 & 4.05 & $3.20-5.78$ & 1.19 & 0.53 \\
2 & IR83835-95-1-1-3 & 4.45 & $3.80-5.39$ & 0.77 & 0.29 \\
3 & BMIP-46-4-1 & 3.86 & $2.24-5.48$ & 1.17 & 0.79 \\
4 & AGH42-2-3 & 3.81 & $2.69-4.96$ & 0.88 & 0.60 \\
5 & AGH43-1-2 & 3.78 & $2.61-5.15$ & 0.92 & 0.55 \\
6 & GH137-7-SKI-B & 3.79 & $2.60-5.10$ & 1.04 & 0.22 \\
7 & B11377F-MR-34-2 & 4.74 & $4.13-6.02$ & 0.67 & 0.45 \\
8 & B11586F-MR-11-2-2 & 4.16 & $3.08-5.63$ & 1.02 & 0.58 \\
9 & B10891B-MR-3-KN-4-1-1-MR-1 & 3.95 & $2.43-5.48$ & 1.27 & 0.38 \\
10 & IR42 (check) & 4.02 & $2.99-5.54$ & 1.14 & 0.34 \\
11 & Inpara2 (check) & 4.33 & $2.96-5.89$ & 1.12 & 0.39 \\
12 & Martapura (check) & 3.22 & $0.70-4.74$ & 0.82 & 1.89 \\
\multicolumn{7}{r}{ Average } & 4.01 & & 1.08 & 0.58 \\
\hline
\end{tabular}

${ }^{2)} \mathrm{Bi}$ : regression coefficient.

${ }^{\mathrm{y})} \mathrm{S}^{2} \mathrm{di}$ : deviation from regression.

\section{DISCUSSION}

\section{Response to abiotic stresses}

In swampy areas, iron toxicity usually occurs due to anaerobic conditions during the wet season. In acidic soils with $\mathrm{pH}$ below 5 , aluminum toxicity will severely affect crop performance and yield. In anaerobic soils, $\mathrm{Fe}$ is reduced to its soluble form, $\mathrm{Fe}^{2+}$, and can be taken up excessively by plants. In plant tissues, $\mathrm{Fe}^{2+}$ participates in Fenton reactions, catalyzing the generation of hydroxyl radicals $(\cdot \mathrm{OH})$ and other reactive oxygen species (ROS) (Thongbai and Goodman 2000). The radicals cause irreversible damage to membrane lipids, proteins and nucleic acids. It could also oxidize chlorophyll and subsequently reduce leaf photosynthesis (Pereira et al. 2013), thereby leading to yield reductions. The typical symptoms associated with iron toxicity are leaf discoloration (bronzing) and reddish spots in the leaf blade (Tanaka et al. 1966). Rice grain yield losses associated with the appearance of bronzing symptoms ranged from $15 \%$ to $30 \%$. In West Africa, rice yield losses associated with iron toxicity is estimated to be $12 \%$ to $100 \%$ (Gunawardena et al. 1982). Makarim et al. (1989) reported yield reduction as much as $90 \%$ in Batu Marta, South Sumatra, Indonesia. Based on reports from various field studies, it can be concluded that each visual bronzing symptom score increment was associated with a yield loss of approximately $400 \mathrm{~kg} / \mathrm{ha}$ (Audebert and Fofana 2009). Generally, crop damage is largest when toxicity occurs at the seedling and early vegetative stages of rice; in the worst case scenario it can lead to a complete failure of the crops (Abraham and Pandey 1989; Abu et al. 1989; Audebert and Sahrawat 2000). The elite lines screened in our study had scores of 1-2 of leaf bronzing and were categorized as tolerant to iron toxicity, which was similar to Mahsuri, the tolerant check, with the exception of line IR83835-95-1-1-3 (Table 1). Therefore, the eight highly tolerant lines can be cultivated in the problematic areas that have chronic iron toxicity problems, including the swampy lands.

Among the nine elite lines screened for submergence, the only line identified as tolerant was B11377F-MR-34-2 (Table 1). Interestingly, based on survey of three SUBI DNA markers, this line does not possess the FR13A-derived SUB1A tolerant allele (Fig. 1); however, $S U B 1 A$ was highly expressed under submergence (Fig. 2). Hence, the tolerance of this line was mainly contributed by $S U B 1 A$. This result was similar with the finding of Septiningsih et al. (2012), where the SUB1A gene in the variety Madabaru, a moderately tolerant variety, was highly expressed under submergence, even though this variety had the 'susceptible' allele $S U B 1 A-2$. Likewise, 
Singh et al. (2010) had reported that the susceptible SUB1A-2 allele identified in the variety James Wee was highly expressed under submergence, despite the fact that this variety was moderately tolerant to submergence. Therefore, for a diversity study, in addition to the use of $S U B 1$ DNA markers it is imperative to check the expression of $S U B 1 A$ to confirm whether $S U B 1$ indeed plays a role in contributing to submergence tolerance.

\section{Response to biotic stresses}

Blast is a predominant disease in rainfed areas in Indonesia, including swampy areas. The combination of well managed cultural practices, fungicides, and resistant varieties are considered to be potential remedies for rice blast disease (Wang et al. 2013). However, resistant varieties are considered to be the most important component and the most economically viable management strategy (Roychowdhury et al. 2012). During the past five years of monitoring, 26 races with various proportions of infections had been identified in Lampung, West Java, South Sumatra (swampy areas), South Kalimantan (swampy areas), and Bali. Out of the 26 races, seven races, which are races $\# 001,023,033,073,101,133$, and 173, were identified in every year. The most infectious races were race \#033, 073, 133, and 173 (Santoso and Nasution 2009). BMIP-46-4-1 is the most resistant elite line that can be planted in the worst areas of blast disease; however, this line has an average grain yield of only $3.86 \mathrm{t} /$ ha (Table 2 , Table 5). Potentially, this line can be used as a resistant donor to develop high-yielding varieties that are resistant to blast. On the other hand, B11377F-MR-34-2 is still a good choice since this line has the highest average yield and is not highly susceptible to blast.

To address BLB, the various pathotypes of Xanthomonas need to be carefully considered based on the target rice production regions and resistance genes deployed in rice varieties. Pathotype III is group of Xoo which has high virulence to Kogyoku, a differential variety for $\mathrm{Xal}$ and Xa12. This group also highly infected Tetep which carries resistant genes $X a 3$ and $X a 2$. But it was less virulent to Wase Aikoku harboring resistant genes Xa3, Xa12, and Java14, a differential variety that carries the genes $\mathrm{Xal}, \mathrm{Xa}$, and Xa12 (Suparyono et al. 2003). Pathotype IV is the most virulent pathotype in Indonesia. Pathotype VIII is highly virulent to differential varieties which carry combinations of $X a 1+X a 12, X a 3+X a 2, X a 3+X a 12$, but it has less virulence to differential varieties with the pyramided genes of $X a 1+X a 2+X a 12$. These three pathotypes were widely spread in all rice production areas in Indonesia; however, Sudir (2012) and Suparyono et al. (2004) reported that the predominant pathotypes were different among provinces or islands. Pathotype III was common in South Sulawesi, while pathotype IV was predominant in North Sumatra. Meanwhile, pathotype VIII was the predominant group on Java Island. This means that different resistant varieties need to be deployed in each region accordingly to control the BLB disease. There are six elite lines that are better than the local checks (IR42, Inpara2, and Martapura) against BLB infection, and B11377F-MR-34-2 was the most tolerant line. Therefore, B11377F-MR-34-2 can potentially be deployed in the regions where BLB is common. The other five lines were still can be used as viable alternative as well; however, other factors such as yield and other abiotic and biotic stress components need to be taken into account.

Tungro virus is also a major disease in tidal swamp areas, especially in Kalimantan. However, thus far, no modern varieties have been identified that are resistant to tungro virus and adapted to tidal swamp areas. B11586F-MR11-2-2 had comparable resistance with the resistant check, Tukad Petanu; while B10891B-MR-3-KN-4-1-1-MR-1 was moderately tolerant (Table 4). Therefore, these two elite lines can be deployed in the swampy areas that are prone to tungro virus infection, including regions of Kalimantan. However, other lines having high yield can still be deployed in the swampy land regions where tungro is not the predominant disease.

\section{Adaptability of swampy rice lines}

The adaptability of the lines to swampy areas was measured by analyzing the $\mathrm{G} \times \mathrm{E}$ interaction on grain yield. Joint regression analysis (JRA) and AMMI are the two methods that can be used to analyze $\mathrm{G} \times \mathrm{E}$ interactions (Asenjo et al. 2003). According to Eberhart and Russell (1966), stable varieties are genotypes which had high mean yield, regression coefficient (bi) close to unity and deviation from regression $\left(\mathrm{S}^{2} \mathrm{di}\right)$ near zero. A variety 
having both of these two criteria as well as high yield will have a good performance in all environments. The result of our study showed that B11586F-MR-11-2-2 had wide adaptability and good average yield ( $4.16 \mathrm{t} / \mathrm{ha})$; however, it is still a bit lower than that of the average of the local check, Inpara2 (4.33 t/ha). Nonetheless, B11586F- MR-11-2-2 is the only line that is highly resistant to tungro virus. Thus, it will be one of the best lines to be deployed in swampy tungro-prone areas. On the other hand, B11377F- MR-34-2 had narrower adaptability, but it had the highest yield (4.74 t/ha). B11377F-MR-34-2 was the best variety to adapt to swampy areas having acid sulphate soil, low soil fertility and complex abiotic and biotic constraints. This is based on yield data from the sulfic acid soil locations in Karang Agung. The yields on this location were $4.51 \mathrm{t} / \mathrm{ha}$ and 5.48 t/ha during WS 2012 and DS 2013, respectively. Nevertheless, based on the range of average yield in nine locations (4.13-6.02 t/ha), this variety can be deployed across many swampy land regions. Other lines which are not tolerant to iron toxicity had more unstable yields across locations.

Among the nine elite lines tested, B11377F-MR-34-2, which was derived from a double cross of Cinglonik/ IRBB7//Memberamo/IR64, had the highest average yield (4.74 t/ha), which was significantly higher than those of the local check varieties (IR42, Inpara2, and Martapura). This line is also tolerant to submergence and $\mathrm{Fe}$ toxicity. B11586F-MR-11-2-2 is the only elite line that had high resistance to tungro virus. This line also has iron toxicity tolerance. It is hopeful that B11377F-MR-34-2 will be rapidly adopted by farmers across the swampy regions; while B11586F-MR-11-2-2 will be rapidly adopted mainly in the swampy areas which are prone to tungro virus. B11377F-MR-34-2 and B11586F-MR-11-2-2 were recently released in Indonesia as Inpara8 and Inpara9, respectively.

\section{ACKNOWLEDGEMENTS}

The work reported here was supported in part by the Indonesian Agency for Agricultural Research and Development (IAARD) to I.A.R. and the Global Rice Science Partnership (GRiSP) to E.M.S.

\section{REFERENCES}

Abraham MJ, Pandey DK. 1989. Performance of selected varieties and advanced generation genotypes in rainfed lowland iron-toxic soil. Int. Rice Res. Newsl. 14: 16.

Abu MB, Tucker ES, Harding SS, Sesay JS. 1989. Cultural practices to reduce iron toxicity in rice. Int. Rice. Res. Newsl. 14: 19.

Alihamsyah T. 2004. Potency and swamp land usage for rice production improvement, p. 327-346. In: F. Kasrino, E. Pasandaran, A.M. Fagi (ed.). Economical of rice in Indonesia (abstract in English). Indonesian Agriculture Agency for Research and Development, Jakarta, Indonesia.

Alihamsyah T, Sarwani M, Ar-Riza I. 2003. Tidal Swamp, a future land for rice production growth, p. 263-287. In: B. Suprihatno, A.K. Makarim, I.N. Widiarta, Hermanto, A.S. Yahya. (ed.). Rice policy and innovation technology (abstract in English). Book 2. ICFORD, Bogor, Indonesia.

Asenjo CA, Bezuz R, Acciaresi HA. 2003. GenotypeEnvironment interactions in rice (Oryza sativa L.) in temperate region using the joint regression analysis and AMMI methods. Cereal Res. Commun. 31: 97-104.

Asikin S. 2015. An environmental friendly of pest and diseases management in swampy areas [Internet]. Ministry of Agriculture Republic of Indonesia, Jakarta, Indonesia. [cited 2016 Sep 18]. Available from: http://balittra. litbang.pertanian.go.id/index.php?option=com_content $\&$ view $=$ article $\& i d=1598 \&$ Itemid $=5$.

Audebert A, Fofana M. 2009. Rice yield gap due to iron toxicity in West Africa. J. Agron. Crop Sci. 195: 66-76.

Audebert A, Sahrawat KL. 2000. Mechanisms for iron toxicity tolerance in lowland rice. J. Plant Nutr. 23: 1877-1885.

Baltazar MD, Ignacio JCI, Thomson MJ, Ismail AM, Mendioro MS, Septiningsih EM. 2014. QTL mapping for tolerance of anaerobic germination from IR64 and the aus landrace Nanhi using SNP genotyping. Euphytica 197: 251-260.

Castillo EG, Tuong TP, Ismail AM, Inubushi K. 2007. Response to salinity in rice: Comparative effects of osmotic and ionic stresses. Plant Prod. Sci. 10: 159-170.

Collard BCY, Kato Y, Septiningsih EM, Ismail AM, Mackill DJ. 2013a. Defining IRRI's role in the EIRLSBN: Current 
status and future directions, p. 135-144. In: B.C.Y. Collard, A.M. Ismail, B. Hardy (ed.). EIRLSBN: Twenty years of achievements in rice breeding. International Rice Research Institute, Manila, Philippines.

Collard BCY, Septiningsih EM, Das SR, Carandang JJ, Sanchez DL, Kato Y, et al. 2013b. Developing new flood-tolerant varieties at the International Rice Research Institute (IRRI). SABRAO J. Breed. Genet. 45: 42-56.

Dixit S, Singh A, Kumar A. 2014. Rice breeding for high grain yield under drought: A strategic solution to a complex problem. Int. J. Agron. doi: 10.1155/2014/863683.

Eberhart SA, Russell WA. 1966. Stability parameters for comparing varieties. Crop Sci. 6: 36-40.

Finlay WK, Wilkinson GN. 1963. The analysis of adaptation in plant breeding program. Aust. J. Agr. Res. 14: 742-754.

Fukao T, Harris T, Bailey-Serres J. 2009. Evolutionary analysis of the $S u b 1$ gene cluster that confers submergence tolerance to domesticated rice. Ann. Bot. 103: 143-150.

Gauch HG, Piepho HP, Annicchiaricoc P. 2008. Statistical analysis of yield trials by AMMI and GGE: Further considerations. Crop Sci. 48: 866-889.

Gonzaga ZJC, Carandang J, Sanchez DL, Mackill DJ, Septiningsih EM. 2016. Mapping additional QTLs from FR13A to increase submergence tolerance in rice beyond SUB1. Euphytica 209: 627-636.

Gregorio GB, Senadhira D, Mendoza RD, Manigbas NL, Roxas JP, Guerta CQ. 2002. Progress in breeding for salinity tolerance and associated abiotic stresses in rice. Field Crops Res. 76: 91-101.

Gunawardena I, Virmani SS, Sumo FJ. 1982. Breeding rice for tolerance to iron toxicity. Oryza 19: 5-12.

Hairmansis A, Aswidinnoor H, Supartopo, Suprihatno B, Suwarno WB, Suwarno. 2013. Yield and grain quality of ten promising rice breeding lines for tidal swamp areas (Indonesian). J. Agron. Indonesia 41: 1-8.

Henry A, Cal AJ, Batoto TC, Torres RO, Serraj R. 2012. Root attributes affecting water uptake of rice (Oryza sativa) under drought. J. Exp. Bot. 63: 4751-4763.

Iftekharuddaula KM, Ahmed HU, Ghosal S, Amin A, Moni ZR, Ray BP, et al. 2016a. Development of early maturing submergence-tolerant rice varieties for Bangladesh. Field Crops Res. 190: 44-53.

Iftekharuddaula KM, Ghosal S, Gonzaga ZJ, Amin A, Barman HN, Yameen R, et al. 2016b. Allelic diversity of newly characterized submergence-tolerant rice (Oryza sativa L.) germplasm from Bangladesh. Genet. Resour. Crop Evol. 63: 859-867.

Iftekharuddaula KM, Newaz MA, Salam MA, Ahmed HU, Mahbub MAA, Septiningsih EM, et al. 2011. Rapid and high-precision marker assisted backcrossing to introgress the SUB1 QTL into BR11, the rainfed lowland rice mega variety of Bangladesh. Euphytica 178: 83-97.

IRRI (International Rice Research Institute), INGER (International Network for Genetic Evaluation of Rice). 2014. Standard evaluation system for rice. Los Baños, Philippines.

Ismail AM, Heuer S, Thomson MJ, Wissuwa M. 2007. Genetic and genomic approaches to develop rice germplasm for problem soils. Plant Mol. Biol. 65: 547-570.

Ismail AM, Tuong TP. 2009. Brackish water coastal zones of the monsoon tropics: Challenges and opportunities, $\mathrm{p}$. 113-121. In: S.M. Haefele, A.M. Ismail (ed.). Natural resource management for poverty reduction and environmental sustainability in rice-based systems. International Rice Research Institute, Metro Manila, Philippines.

Kato Y, Collard BC, Septiningsih EM, Ismail AM. 2014. Physiological analyses of traits associated with tolerance of long-term partial submergence in rice. AoB Plants 6 . doi: 10.1093/aobpla/plu058.

Kretzschmar T, Pelayo MA, Trijatmiko KR, Gabunada LF, Alam R, Jimenez R, et al. 2015. A trehalose-6-phosphate phosphatase enhances anaerobic germination tolerance in rice. Nat. Plants 15124. doi: 10.1038/nplants.2015.124.

Kumar A, Bernier J, Verulkar S, Lafitte HR, Atlin GN. 2008. Breeding for drought tolerance: Direct selection for yield, response to selection and use of drought-tolerant donors in upland and lowland-adapted populations. Field Crops Res. 107: 221-231.

Li ZX, Septiningsih EM, Quilloy-Mercado SM, McNally KL, Mackill DJ. 2011. Identification of SUB1A alleles from wild rice Oryza rufipogon Griff. Genet. Resour. Crop Evol. 58: 1237-1242.

Makarim K, Sudarman O, Supriadi H. 1989. Rice nutrient status in Fe toxic area of Batumarta, Sumatra Selatan (Indonesian). J. Penelit. Pertan. Tanam. Pang. 9: 166-170.

Neeraja CN, Maghirang-Rodriguez R, Pamplona A, Heuer S, Collard BC, Septiningsih EM, et al. 2007. A markerassisted backcross approach for developing submergencetolerant rice cultivars. Theor. Appl. Genet. 115: 767-776. 
Niroula RK, Pucciariello C, Ho VT, Novi G, Fukao T, Perata P. 2012. SUB1A-dependent and -independent mechanisms are involved in the flooding tolerance of wild rice species. Plant J. 72: 282-293.

Nugraha Y, Ardie SW, Ghulammahdi M, Suwarno S, Aswidinnoor H. 2016. Nutrient culture media with agar is effective for early-and rapid-screening of iron toxicity tolerant in rice. J. Crop Sci. Biotech. 19: 61-70.

Pereira EG, Oliva MA, Rosado-Souza L, Mendes GC, Colares DS, Stopato CH, et al. 2013. Iron excess affects rice photosynthesis through stomatal and non-stomatal limitations. Plant Sci. 201-202: 81-92.

Roychowdhury M, Jia YL, Cartwright RD. 2012. Structure, function and Co-evolution of rice blast resistance genes. Acta Agron. Sin. 38: 381-393.

Sahrawat KL. 2005. Iron toxicity in wetland rice and the role of other nutrients. J. Plant Nutr. 27: 1471-1504.

Santoso, Nasution A. 2009. Management of blast and other fungus diseases, p. 531-563. In: Innovation of rice production technology. Book 2. Indonesian Center for Rice Research, Subang, Indonesia.

Septiningsih EM, Collard BCY, Heuer S, Bailey-Serres J, Ismail AM, Mackill DJ. 2013a. Applying genomics tools for breeding submergence tolerance in rice, p. 9-30. In: R.K. Varshney, R. Tuberosa (ed.). Translational genomics for crop breeding 2: Abiotic stress, yield and quality. John Wiley and Sons Inc., Hoboken, NJ.

Septiningsih EM, Hidayatun N, Sanchez DL, Nugraha Y, Carandang J, Pamplona AM, et al. 2015. Accelerating the development of new submergence tolerant rice varieties: The case of Ciherang-Sub1 and PSB Rc18-Sub1. Euphytica 202: 259-268.

Septiningsih EM, Ignacio JC, Sendon PM, Sanchez DL, Ismail AM, Mackill DJ. 2013b. QTL mapping and confirmation for tolerance of anaerobic conditions during germination derived from the rice landrace Ma-Zhan Red. Theor. Appl. Genet. 126: 1357-1366.

Septiningsih EM, Pamplona AM, Sanchez DL, Neeraja CN, Vergara GV, Heuer S, et al. 2009. Development of submergence-tolerant rice cultivars: The Subl locus and beyond. Ann. Bot. 103: 151-160.

Septiningsih EM, Sanchez DL, Singh N, Sendon PM, Pamplona AM, Heuer S, et al. 2012. Identifying novel QTLs for submergence tolerance in rice cultivars IR72 and Madabaru. Theor. Appl. Genet. 124: 867-874.
Shah SM, Arif M, Aslam K, Shabir G, Thomson MJ. 2016. Genetic diversity analysis of Pakistan rice (Oryza sativa) germplasm using multiplexed single nucleotide polymorphism markers. Genet. Resour. Crop Evol. 63: 1113-1126.

Singh N, Dang TT, Vergara GV, Pandey DM, Sanchez D, Neeraja CN, et al. 2010. Molecular marker survey and expression analyses of the rice submergence-tolerance gene SUB1A. Theor. Appl. Genet. 121: 1441-1453.

Singh R, Singh Y, Xalaxo S, Verulkar S, Yadav N, Singh S, et al. 2016. From QTL to variety-harnessing the benefits of QTLs for drought, flood and salt tolerance in mega rice varieties of India through a multi-institutional network. Plant Sci. 242: 278-287.

Singh S, Mackill DJ, Ismail AM. 2009. Responses of Sub1 rice introgression lines to submergence in the field: Yield and grain quality. Field Crops Res. 113: 12-23.

Sudir. 2012. Mapping of Xanthmonas oryzae pv. oryzae, patogen of bacterial leaf blight in rice production areas of Java island (abstract in English) Book 1. Proceeding of the Rice National Seminar. Indonesian Center for Rice Research, Subang, Indonesia.

Suparyono, Sudir, Suprihanto. 2003. Pathotype composition of bacterial leaf blight pathogen in the different growth stage (abstract in English). J. Penelit. Pertan. 22: 45-50.

Suparyono, Sudir, Suprihanto. 2004. Pathotype profile of Xanthomoas campestris pv. oryzae, isolates from the rice ecosystem in Java. Indones J. Agric. Sci. 5: 63-69.

Tanaka A, Loe R, Navasero SA. 1966. Some mechanisms involved in the development of iron toxicity symptoms in the rice plant. Soil Sci. Plant Nut. 12: 32-38.

Thomson MJ, de Ocampo M, Egdane J, Rahman MA, Sajise AG, Adorada DL, et al. 2010. Characterizing the Saltol quantitative trait locus for salinity tolerance in rice. Rice 3: $148-160$.

Thomson MJ, Ismail AM, McCouch SR, Mackill DJ. 2009. Marker assisted breeding, p. 451-469. In: A. Pareek, S.K. Sopory, H.J. Bohnert (ed.). Abiotic stress adaptation in plants: Physiological, molecular and genomic foundation. Springer, Dordrecht.

Thongbai P, Goodman BA. 2000. Free radical generation and post-anoxic injury in rice grown in an iron-toxic soil. J Plant Nutr. 23: 1887-1900.

Toledo AMU, Ignacio JCI, Casal C, Gonzaga ZJ, Mendioro MS, Septiningsih EM. 2015. Development of improved 
Ciherang-Sub1 having tolerance to anaerobic germination conditions. Plant Breed. Biotechnol. 3: 77-87.

Wang JC, Jia Y, Wen JW, Liu WP, Liu XM, Li L, et al. 2013. Identification of rice blast resistance genes using international monogenic differentials. Crop Prot. 45: 109-116.

$\mathrm{Xu} \mathrm{K,} \mathrm{Xu} \mathrm{X,} \mathrm{Fukao} \mathrm{T,} \mathrm{Canlas} \mathrm{P,} \mathrm{Maghirang-Rodriguez} \mathrm{R,}$
Heuer S, et al. 2006. SublA is an ethylene-responsefactor-like gene that confers submergence tolerance to rice. Nature 442: 705-708.

Zheng K, Subudhi PK, Domingo J, Magpantay G, Huang N. 1995. Rapid DNA isolation for marker assisted selection in rice breeding. Rice Genet. Newsl. 12: 255-258. 